\title{
Ukraine between Russia and the European Union: Triangle Revisited
}

Ukraine has long been considered as a bone of contention between the EU and Russia which could eventually lead to a split of the country along political, cultural or religious lines. This interpretation, however, fails to explain the dynamics of the Ukrainian revolution and the Russian-Ukrainian war. To address the deadlock in understanding the complex situation in Ukraine, this article argues that the relations in the triangle EU-Ukraine-Russia is affected by the combination of choices made by the Ukrainian political class, business elites and broader society in four major dimensions: internal political practices, economic international politics, and ideological dimension.

\section{FORTHCOMING AS PUBLICATION: PLEASE DON'T CIRCULATE}

Keywords: geopolitics, democratisation, Ukraine, Russia, European Union

\section{Introduction}

Ukraine has been repeatedly described as an apple of discord, bone of contention, root of disagreement between Russia on the one hand, and the EU on the other. To some extent this interpretation of EU-Ukraine-Russia triangle resonates with general studies which construe EU-Russia interaction as reflecting a clash of various irreconcilable dichotomies (e.g. a vegetarian elephant vs. a bear (Emerson, 2001), post-modern EU vs. modern, or, even premodern Russia (Cooper, 2011), EU integrationist vision vs. Russian geopolitical mentality) (Gomart, 2006). In analyses of this kind Ukraine is reduced to a mere object of Russia-EU competition. However insightful and empirically rich, this approach cannot explain Ukraine's predicament in making a geopolitical choice between Russia and the EU. If Russia and the EU had engaged in some sort of fundamental conflict over Ukraine, the latter would have become a battleground for fierce competition and would have been torn asunder by the two actors and split into a pro-European Ukrainian part and a pro-Moscow Russian-speaking part. Some might argue that Russia's annexation of Crimea and unrest in the East of Ukraine are manifestations of the conflict between pro-European Ukrainians and pro-Moscow Russophones. However, such an interpretation cannot explain the fact that the Maidan activists in November 2013 included both an Ukrainian ultranationalist groups and a predominantly Russian-speaking population of the Ukrainian capital Kyiv and other regions. It also fails to explain why the significant part of the the Russophone population in the South and some Eastern regions of Ukraine strongly supports the European trajectory of Ukraine and opposes the separatist movement.

The problématique above suggests that Russia-EU interaction in their shared neighbourhood is informed by a dynamic which is more complex than mere ideological or geopolitical competition. Some attempts to move beyond the above reductionism from institutionalist and constructivist standpoints were made by Haukkala (2001), (2008) and Prozorov ( 2006). Attributing the same - "integrationist" and "sovereign" features to Russia and the EU, Prozorov explains boththe cases of collaboration and conflict in Russia-EU interaction. This trend has recently been applied in the research of the Black Sea region. In their exploration of 
the Black Sea region, some authors problematize the imperial paradigm and the representation of Russia as a barbarian, imperial 'other' for the West (Ciută, 2007, Ciută, 2008). Others acknowledge that it was the EU that was inconsistent in its policies in the region (Delcour, 2010), (Nitoiu, 2011) and reluctant to engage Russia in EU policies for the region(Najšlová, 2010). They also point to the need for the EU to engage Russia in joint actions(German, 2007). While other authors challenge the "conflictual" paradigm, by pointing to numerous examples of EU-Russia cooperative behaviour in the post-Soviets space, in conflict resolution (Hill, 2012), or in Justice and Home Affairs (Potemkina, 2010).

Drawing on the above critique this paper suggests that the regional projects of Russia and the EU in their shared neighbourhood produce a more complex effect on the region. Therefore, Ukraine's predicament concerning its geopolitical choice should be studied at the sub-unit level of analysis. To conduct such an analysis this paper applies Luk van Langenhove's conceptualisation which defined regions as projects, made up of a set of social actors and aimed at organising society on different dimensions such as the political, the economic and the social. (Langenhove, 2003, Langenhove, 2011). Applying Langenhove's conceptualisation, it holds that there are three significant social actors - government, society and business elites. Since the three actors often have divergent interests and/or motives for action, it is suggested that a state should not be construed as a rational system and the state's regional orientations should be treated as outcomes of balance of preferences and practices between the three actors rather than a rational choice.

Within the same logic the paper argues that the interests of these actors may differ in the various dimensions - the social, the political and the economic, which means that the balance of preferences will differ in various dimensions. To ascertain this relations in the triangle EU-Ukraine-Russia will be examined across four major dimensions of societal interaction: internal political practices, economic and social-ideological dimension. In addition, it is necessary to analyze the dimension of international security politics which is an important indicator of regional alignments of Ukraine. The paper will analyse each dimension and will identify in which of them preferences of main actors generate zero-sum logic. For the present purpose, the phrasings "zero-sum dynamics" implies that he EU and Russia each pursue their own objectives, which to a great extent are mutually exclusive or even antagonistic. In the framework of this "zero-sum logic", the future of Ukraine has been framed as a dichotomy: "either with Europe or with Russia".

\section{Slicing the EU-Ukraine-Russia triangle}

Until recently relations in the triangle EU-Ukraine-Russia were depicted as a more or less homogenous complex of zero-sum dynamics. In particular, it has been widely acknowledged that:

1. In the dimension of internal political practices: each of the two actors are trying to introduce in Ukraine those political practices which correspond to their values, visions or interests. Thus, the EU seeks to encourage Ukraine to pursue transparent democratic procedures and respect human rights, whereas Russia tries to implement its own sovereign democracy model. These models were considered antagonistic and generated zero-sum dynamics for Ukraine's choice. 
2. in the economic dimension: each of the two actors are trying to open Ukrainian markets for their economic agents and to create more favourable conditions for transborder trade with and economic activities in Ukraine through the DCFTA or through the Customs Union, which were mutually exclusive and, thus, Ukraine's choice between the two project was seen in zero-sum terms.

3. in the dimension of foreign policy and international security architecture: EU and Russia seek to involve Ukraine in their security projects - the EU is seeking Ukraine's alignment with CFSP decisions and its participation in various CSDP missions, with some EU Member State advocating Ukraine accession to NATO, whereas Russia is seeking to involve Ukraine both in closer security partnership, bilateral or multilateral Tashkent pact, or, at least, to secure its neutrality. Given Russia's sensitivity about Ukraine's accession to NATO, the dilemma was also framed in zero-sum terms.

4. in the ideological dimension both Russia and the EU offer Ukraine their respective ideology and their particular perception of history. Russia's ideology has been developed in recent times through the appreciation of its unique national character and extreme experiences, which are regarded as justifying Russia's right to seek its own unique way to become 'a normal' European country. Thus, Russia offers Ukraine an ideology based on glorification of their shared Soviet and pre-Soviet past, common culture and language. The EU, in turn, offers Ukraine its own post-modern understanding of Europe based on human rights, freedoms and liberties, which make the EU a sort of teleological point of the development of any human society. At the same time, Ukraine's rejection of its Soviet past and history and focus on its own trauma and promotion of its own language, seem to be important element of Ukraine's modern nation-building programme and return to Europe. It was suggested that the two programmes were antagonistic and defined Ukraine's choice in zero-sum terms.

The paper will analyze each of the above dimensions and identify the preferences of the three main societal actors in Ukraine - the government, business elites and population. The analysis of the balance of preferences of the three actors will help account for the dynamics in the triangle. In addition to a more refined analysis, this approach allows for attributing a certain degree of agency to Ukrainian actors. This agency is clearly exercised when the interests and motivations of two of the three major societal actors coincide and lead to shaping a certain policy choice. Quite often such a choice is neither explicitly pro-European nor pro-Western, which demonstrates Ukraine's ability to diminish the zero-sum dynamics in the triangle.

The paper also analyses changes in the interests of the EU and Russia across different dimensions. The balance of preferences will demonstrate where zero-sum dynamics prevails, i.e. where the interests of EU and Russia are likely to remain irreconcilable, and where different dynamics can be identified. Overall, the paper will also look at how changes in the dynamics within one dimension affect its interface with other dimensions.

\section{Dimension of the internal political practices: Euromaidan or Revolution of Dignity}


The dominant narrative of the last year's events in Ukraine contends that the pro-European, democratically-minded Ukrainian public rallied against authoritarian President Viktor Yanukovich after he refused to sign the EU-Ukraine Association Agreement in November 2013. The Ukrainian revolution, often branded as Euromaidan, is described as a civilizational choice of the Ukrainian people for democratic European values and against authoritarian Russia. Indeed, Ukrainian elites constructed a strong link between the nation's renaissance and historical return to Europe on the one hand, and the country association with the EU on the other. Drawing on this link, the EU could build up strong moral authority in Ukrainian politics. Twenty-seven visits by Cox-Kwasniewski mission to Ukraine, regular presence of EU diplomats in the court sessions against the opposition leaders and frequent reminders from top level Brussels officials that the EU-Ukraine association agreement will be signed only if the problem of selective justice will be resolved created the link between political and economic dimension. In addition, the strong response of the EU to politically motivated criminal processes against the leaders of the opposition resonated with the demand of the society and added additional significance to the political debate in 2011-2013. As a result, this internal debate was gradually reframed from a purely government-opposition conflict into a broader discourse about Ukraine's return to Europe. All this made the soft power of the EU stronger and provided it with some leverage in Ukrainian politics.

However, the link between the economic and political dimension should not be taken for granted. The rallies in support of EU-Ukraine Association Agreement organised by proEuropean intelligentsia and opposition parties on the eve of the Vilnius Eastern Partnership Summit gathered about 50-70 thousand people in the Ukrainian capital, Kyiv. However these large rallies did not lead to mass mobilisation and radicalisation of the protests. On the contrary, a week later 31 November these rallies phased out. The mass mobilisation and violent protests that eventually led to overthrowing President V. Yanukovich took place after the night of 31 November, when the riot police brutally dispersed a small number of students and some journalists, who decided to spend the night in Independence Square. The acts of unmotivated violence by the Ukrainian riot policy were broadcast widely and triggered mass mobilisation of Kyiv residents and inflow of protestors from other cities. The main slogan of the second wave of protests - "we won't let these bandits to kill our children" - had nothing to do with the EU-Ukraine Association Agreement (2013). The protests, which were rebranded from the 'Euromaidan' to the Revolution of "Dignity", brought together the broadest spectrum of social and political forces ranging from extreme Ukrainian nationalists with their anti-EU slogans to some religious communities and Russian-speaking retired army officers. Therefore, the Ukrainian democratic revolution was more against Yanukovich's government rather than for the Association with the EU. It was part of another significant trend in Ukrainian politics that can be explained in the broader framework of Yanukovich's "authoritarian project".

Having taken office, President Yanukovych tried to replicate political practices borrowed from Russia, e.g. by concentrating executive power in his hands, substituting democratic procedures with imitations, simulating public competition with pre-selected sparring partners rather than with real opposition, and exerting pressure on the society, media and business sectors (Wilson, 2005). One could add other elements here, such as general post-Orange apathy, weakness of civil society in Ukraine(D'Anieri, 2011) and a weak social basis of proWestern NGOcracy in the country, to draw pessimist conclusions about the future of the country (Lutsevych, 2013). Nevertheless, replication of the Russian model of governance in Ukraine did not produce analogous societal and political outcomes in Ukraine. In fact, a 
combination of a number of internal and external structural factors produced the opposite effect. Even well before the Vilnius Summit, President V. Yanukovich faced serious popular resentment and tension in his elite base. The next section pinpoints some crucial factors which play an important role in the launch of "authoritarian projects" and will assess and compare parallels between Russian authoritarianism and its Ukrainian replica.

\subsection{Russian Model in Ukraine: Economic Basis, Government and Population}

In 2001-2002, Vladimir Putin launched the implementation of an authoritarian regime combined with progressive economic reforms and deregulation of small and medium business(Aslund, 2008). These measures in combination with a growing inflow of petrodollars helped the Russian President buy the loyalty of the population. The war against Chechen rebels and general disappointment with the West were also a plausible excuse for gradually limiting the public sphere. Unlike his Russian prototype, Ukrainian President V. Yanukovich took over the office in the conditions of a global economic crisis, with Ukrainian industries being negatively affected by the drop in the demand on the Ukrainian metals and chemical products on the world markets. This external condition drove the Ukrainian government to introduce serious austerity measures and reforms aimed at optimizing budgetary spending and facilitating economic growth.

The problem was that these reforms went against populist electoral promises by Yanukovich. Instead of reducing tax, the new taxation code increased the tax-burden and posed arbitrary economic pressure on small and medium enterprises. Instead of raising pensions the government raised the retirement age. With all this taking place in the context of several scandals involving the embezzlement of public funds in energy/infrastructure projects and exuberant expenses for to the president's residences, a geographic reconciliation gradually took place in Ukraine. Once divided across geographic lines (East vs. West), the country was uniting in/through its rejection of Yanukovych policies.(Dymov, 2012). This widespread opposition produced two waves of mass social protests in the Ukraine: 'Entrepreneurial Maidan' (small traders protests in autumn 2010) and 'Maidan of Afghan War Veterans' (autumn 2011) ${ }^{1}$

The two Maidans point to new trends in Ukrainian society. First, the imaginary geographic divide between East and West or between Russo-phone and Ukrainians was gradually substituted by a discourse of clashes between "'normal' people regardless of their language" vs. "bandits' power". It is indicative that the movement of Afghan War Veterans has its social base in Eastern Ukraine, including Yanukovich's stronghold, the Donetsk region. It cannot be claimed that the entire population has totally rejected radical nationalist ideology (either ethnic Ukrainian nationalism or pro-Soviet/Russian leftism). But the dominant discourse in the society has turned towards ideals of social redistributive justice or neo-liberal economic policies for everyone (Gatskova, 2013).

It can thus be concluded that the implementation of a Russian authoritarian model in Ukraine lacked the necessary economic base and, consequently, produced the opposite effect, namely mobilization of the population and broader societal demand for redistributive justice. Unlike an "idealist civil society of intelligentsia" or a West-funded NGO-cracy, which, despite their

\footnotetext{
${ }^{1}$ Maidan (Ukr. Market/central square) - is widely used to connote the Orange Revolution protests which took place in the Maidan Nezalezhnosti (Independence Square in Kyiv). The fact that subsequent protests of 2010, 2011 were also named maidans demonstrate the significance that Ukrainians attach to these events.
} 
noble goals, have a weak social foundation, the protests by small traders and retired paratroopers have been results of a genuine bottom-up drive, which are beginning to overcome what D. Lane defined as a mainly negative consequence of the coloured revolution, a confrontational and destructive paradigm. (Lane, 2009). However materialistic their motives, - Afghan veterans demanded to keep their high pension rates and traders rallied for maintaining their tax exemptions - these movements have a broad social basis, nation-wide membership and self-sufficiency.

\subsection{Relations between Government and Elites}

Another factor that affected the Russian authoritarian model in Ukraine was the character of relations between the government on the one hand, and the parliamentary institutions and business elites on the other. After the Duma election in 1999, V. Putin could rely on a significant pro-presidential majority in the Russian parliament. Apart from the dogmatic Communist party and small centrist and centre-right factions, there was almost no noticeable meaningful liberal parliamentary opposition. Therefore, the implementation of administrative centralisation in Russia took place in more favourable conditions.

In the case of Ukraine, President V. Yanukovich started political centralisation when the Ukrainian parliament had significant opposition factions. Although compromised by the postOrange period, the Parliament remained an important national site for political debate, particularly in the face of the controversial policies put forward by the new government. The disappointment and the demand for new political forces was demonstrated by the success of the two new parliamentary parties in the 2012 parliamentary elections: the centrist party Udar of Vitaliy Klychko and the Ukrainian nationalist party Svoboda. According to sociologists, Klychko owed his popularity to the fact that he has never been a professional politician(Mishchenko, 2012a); whereas the success of radicals from Svoboda demonstrates voters' preferences to consistent and value-based parties. All the opposition parties seem to have realised the great potential of non-partisan civil society and have started working closely with its most active representatives to forge alliances.

Finally, unlike Russia, the smaller size of the Ukrainian economy and fewer lucrative business assets, did not allow the Ukrainian president to secure an advantageous role in interaction with business elites similar to that of V. Putin's in Russia. In addition, the strong business interests of the President's family raised concerns among major businesses about their future. (Leshchenko, 2013) Over the period 2010-2011, only two oligarchs (Renat Akhmetov and Dmytro Firtash)out of nine major industrialists represented in the first Yanukovich's government maintained their representation in the top executive positions. (Alsund, 2012).Some experts believe that no oligarch, including those who keep a low profile, could feel safe after the Tymoshenko case.(Shevchenko, 2013) Some of them moved their assets to Europe from where they continued to support some opposition movements. Even major industrialists from Ukraine's industrial East, who have been long-time sponsors of the Party of Region, allocated additional funds to the local branches of Tymoshenko's Bloc, Udar, Svoboda and other political parties. As a result of the growing tension between Yanukovich and big business, several oligarchs, including his close associate S. Lyovochkin, withdrew their support from President V. Yanukovich at the peak of the protests. They also helped to secure a peaceful transition of power after V. Yanukovich fled the country on 21 February 2014. 


\subsection{Russia, EU and the Ukrainian democracy}

The argument about Russia's resentment about the coloured revolutions suggests that Moscow a) treated the coloured revolutions in the post-Soviet states as Western geopolitical plots, and b) aimed to export authoritarian models to these countries(Howarth, 2011). The deterioration of relations between Russia and the coloured democracies in Ukraine, Georgia and Kyrgyzstan in 2003-2008 seems confirm this interpretation. At the same time, the claim that Russia seeks to build a special relationship with post-Soviet countries on the basis of ideological affinity and promote authoritarianism is not entirely valid for several reasons. Firstly, Russia has never opposed the democratic revolutions per se. In Georgia, in 2003, Russia even played a positive role in the Georgian Revolution of Roses. It facilitated the removal of the incumbent President Shevarnadze and consolidation of the new government headed by Mikheil Saakashvili. In Kyrgyzstan, Russia supported President Kurmanbek Bakiyev for two years and only withdrew its support when it became clear that these democratic leaders tried to outbalance Russia's influence in their republics through closer alliance with the West (Marat, 2010). For the same reason, in the case of Ukraine, leading Kremlin spin-doctor Gleb Pavloskiy acknowledged that Russia opposed the democratic leader V. Yushchenko mostly because it suspected him of strong anti-Russian sentiment and close ties with the US (Izvestia, 2004). Therefore, the major factor that affects Russia's attitude to democratic revolutions is not the revolution per se, but the perceived ideology behind this revolution and the pro-Western geopolitical orientation that it can bring.

Moreover, its own authoritarianism notwithstanding, Moscow can more effectively project its influence and expand its economic presence in democratic societies rather than in autocratic systems. In the case of Ukraine, Moscow realised that it could secure better economic deals under "pro-Western Orange puppets", rather the fraternal pro-Russian Party of the Regions. Ukrainian nationalist Prime-Minister Y. Tymoshenko signed a highly profitable gas contract for Gazprom in 2009. She was then convicted for this under "pro-Russian" President Yanukovich who tried to re-negotiate the contract. When Moscow refused to re-consider the conditions of the gas deal, V. Yanukovich exercised pressure on several Russian energy companies (Milov, 2011), which demonstrated that Ukraine can also manipulate RussianUkrainian energy interdependence. Similarly, in Belarus and Central Asia, pro-Russian authoritarian leaders became even less comfortable interlocutors for Moscow than the proWestern nationalist leaders in Ukraine. As a result, it suited a profit-minded Russian foreign policy better to promote European democratic political culture in Ukraine (Tsymbaliuk, 2012, Interview, 2011). So ideology apart, democratic systems seem to be the framework in which Russia is able to play a greater role in the political debate in Ukraine, to exercise its soft and economic power, to articulate its narrative in international affairs and defend its interests.

One can conclude that Russia's uneasy feeling about democratic revolutions is a function of how Moscow perceives the outcomes of these revolutions. As long as Russia can maintain its strategic influence over the territory, it has no prejudice as to the form of government in place. Noticeably, after Russia's annexation of Crimea and creation of pro-Russian enclaves in the East of Ukraine, Moscow effectively recognized the newly elected centrist President Poroshenko. The state-controlled Russian media started to wrap-up the militant rhetoric against "Ukrainian Kiev junta" and stopped broad-casting press-conferences with former President Yanukovich. Therefore, the internal political system has currently ceased to 
generate zero-sum political logic. At this stage, Moscow's interest rests with a more democratic Ukraine. This interest will not push Russia to pursue active policies of democracy promotion. However, it will prevent Moscow from pursuing counter-democratic restorations. It is in this democratic landscape that Russia can promote its economic interests in Ukraine as will now be discussed

\section{Economic dimension}

In the economic dimension, the zero-sum logic was generated by attempts by Russia and EU to open up Ukrainian markets to their economic actors and create more favourable conditions for trans-border trade and economic activities through the Deep Comprehensive Free Trade Area (DCFTA) or through the Customs Union with Russia, Kazakhstan, and Belarus (CU). Russia has attached great importance to the Customs Union and Ukraine's accession to the block. President Putin personally advertised the benefits of the CU for Ukraine on several occasions and stressed the disadvantages of Ukraine's independent bargaining with both WTO and the EU. In particular, he stressed that the joint negotiations of the Customs Union would allow the bloc to get import tariffs on goods coming from the countries of WTO which were twice as high as those granted to Ukraine during its bilateral negotiations with WTO and that Ukraine could gain as much as 6-9 USD billion a year when acceding to the Customs Union. (Vladimir Putin, 2011), (Obozrevatel', 2011), (RIA, 2011) . To make the prospect even more attractive, the Russian President went so far as to promise that Ukraine would be entitled to collect the export tax on all the volumes of gas and oil pumped by Russia and Kazakhstan through its territory. At the same time, Putin's close associates have repeatedly stated that Ukraine's accession to DCFTA would close the door to the Customs Union for Ukraine (Rosbalt, 2013). Russian experts produced various reports where they tried to show immediate advantages of the ECU and disadvantages of the DCFTA for Ukraine (Delcour and Wolczuk, 2013, p. 191).

The EU has also contributed to generating zero-sum dynamics in the economic dimension. First, the "take it or leave it approach" adopted by the EU in negotiating DCFTA with the countries of the Eastern Partnership made impossible any adjustment which could address Russia's concerns at the expert level (Delcour and Wolczuk, 2013, pp. 184-186).Secondly, EU officials made it clear that while free trade area with Russia is fully compatible with the DFCTA, the accession of Ukraine to the Customs Union would make DFCTA with the EU impossible. On the eve of the EU Big Enlargement in 2004, Moscow and Brussels engaged in numerous negotiations and addressed most of Russia's concerns ranging from trade agreements with Poland and Bulgaria to a transit regime between Russia and the Moscow enclave of Kaliningrad. No similar meaningful trilateral discussion to address Russia's concerns took place in the case of Ukraine, which escalated the zero-sum logic in the economic dimension.

The broader Ukrainian society was clearly divided over this issue of integration with the EU, with about $70 \%$ of population in the West and the Centre supporting it and $60 \%$ in the SouthEast voting for integration with Russia (IFES Public Opinion in Ukraine 2013: Key Findings, 2013, p. 3). At the same time, most Ukrainian government and business sector have for the most parttried to escape this binary vision. Ukrainian governments have traditionally pursued the pragmatist economic foreign policy, which would to reconcile free-trade with Russia (CIS) and the EU. Even though former President V. Yanukovich and the Party of the Regions 
were often described as pro-Russian or Moscow proxies, there is strong evidence that their approach did not deviate from the pragmatist economic foreign policy.

Pro-Russian business and political elites in the government of Yanukovich had a number of strong concerns about the Customs Union and they supported association with the EU (Zarembo, 2012). Their key concern was that the Customs Union would pave the way for the creation of supranational regulatory bodies which were to decide on the common tariff policy and on disputes and procedures. Despite the formal principle of consensual decision-making in the Board of the Eurasian Economic Commission, it was clear that the weight of Putin's close associate and Russian representative V. Khristenko, in this decision-making body was more than significant. In the existing political architecture in Kremlin, Russian companies would have much stronger lobbying capacities, which would inevitably place Ukrainian businesses in an underprivileged position and eventually lead these businesses to be taken over by their stronger and more aggressive Russian counterparts.

Another reason for scepticism was a great disappointment about the deals reached between Kiev and Moscow on gas discounts and basing rights for the Russian fleet in Crimea. In particular, after the Party of Regions secured the prolongation of Russia's basing rights in Sebastopol, the discount on gas prices that Ukraine received from Moscow was considered less than symbolic (Interview, 2012a) A growing number of gas pipelines constructed by Russia in order to bypass Ukraine became strong evidence that Russia does not want to share with Ukraine part of its gas rent and reduces Ukraine's transit potential and, consequently, its revenues from transit and export of the Russian gas. In this context, Moscow's offer to collect export tax on all gas pumped through Ukraine seemed too good to be true. The disappointment resulted in a number of practical measures that the Yanukovich government adopted in order to reduce Ukraine's gas dependence on Russia. Despite lack of transparency in the energy and electricity projects in 2010-2013, Ukraine switched many of its electricitygenerating capacities from natural gas to coal. Kiev also enlisted investors for constructing LNG terminal, signed agreement with the Shell for extraction of shale gas and looked for alternative gas delivery routes via Azerbaijan and Turkey. (Azarov, 2012).(Storozhev, 2012).Finally, although the risks of living and making business in developing markets offers high profits, Yanukovich and his business and political elite sought safe havens in the European Union. Old Ukrainian business groups not only moved their headquarters and assets to Europe, they also pressured the government to create better conditions for integration of Ukrainian businesses in Europe (Gavrilechko, 2010). Pro-Russian as they were, President V. Yanukovich and his family developed business activities in the European markets.

The above considerations were serious enough to outweigh all the potential benefits of accession to the Customs Union and opt for the DCFTA. Under Yanukovich, Ukraine continued to maximize its commitments to the DCFTA by adopting as many EU technical norms as possible (Langbein and Wolczuk, n.d., p. 867). The fact that Yanukovich appointed two of his closest associates - Head of the National Securtiy Council Sergei Klyuev and Vice-Premier Sergei Arbuzov - to negotiate DCFTA and upgraded the status of the Ukrainian Ambassador to the EU to the level of the State Representative, demonstrates the importance of the European dimension in this case (Yanukovich, 2013). The appointment of the highly respected centrist businessman and politician Petro Poroshenko to the position of the Minister of Economic Development and his skilful mitigation of the 'cheese war' between Russia and Ukraine in March 2012 was another indication that Yanukovich has prepared to 
depoliticize the economic dimension and confine these relations to the technical domain. At the same time, Yanukovich has been meticulous in purging out any provision that would imply supremacy of the Free Trade Area in the CIS over the DCFTA with the EU(Levy Bereg, 2012).

Certainly, Ukraine's decision to sign the DFCTA was sold to Russia and other international as an absolute pragmatist move aiming at linking Ukraine to the international market of 600 million comparatively rich Europeans. To save both Russia's and its own face when rejecting Russia's offer, Kyv offered an alternative formula ' $3+1$ ' which would allow Ukraine to maintain special status in relations with the CU given its special commitments to DFCTA. The alternative formula ' $3+1$ ', essentially Free Trade Area with the countries of the Customs Union was the highest degree of integration to which Ukrainian elite would be ready to accept. Another important concession from Kiev was the offer to grant the Russian energy giant Gazprom preferential treatment in the privatisation of Ukrainian regional energy distribution companies and their download capacities.(Topalov, 2011).

Despite all Kiev efforts, Russia still viewed the EU-Ukraine trade deal as a threat to the Customs Union. President Putin repeatedly stated that after the EU-Ukraine deal Russia would face a huge inflow of cheap European consumption goods. At the same time, the Russian leader never specified what those cheap and high-quality European consumption goods were. More importantly, Putin repeatedly stressed that the EU-Ukraine deal was negotiated without taking note of Russia's concerns. In the trade war that followed, Russia exerted pressure against those Ukrainian companies, whose owners were close to President Yanukovich and could influence him (Pololvetsky, 2013). With the growing budget deficit, looming gas crisis and complaints from major industries, V. Yanukovich made his signing of the DCFTA conditional on the allocation of significant EU financial support amounting to 160 billion Euro and invited Brussels and Moscow to start trilateral negotiations, an idea which Moscow immediately supported. These two proposals were rejected by the EU and stirred the first wave of protests of pro-European activists on 21-30 November 2013.

The economic dimension might look like the most conflict-prone one because of these clashing preferences. However, it should be noted, that the first wave of protests in Kiev and other major centres of Ukraine directly affected by the EU-Ukraine trade deal did not provoke any significant civil conflict or geographical clash. It was mostly peaceful and involved art-related activities, which generated no violence or any politically-geared agenda. Protestors refused to give the floor to the opposition leaders, so neither the government nor pro-Russian oligarchs saw it as a threat. By 30 November 2013, most of the protests phased out and most likely would have ended up with nothing. As mentioned above, it was the excessive violence by the riot police which triggered mass mobilisation and radicalisation of the protests. Even though it might be argued that Ukrainians were fighting for European values of freedom of assembly and speech, this fight was only marginally related to the EUUkraine DCFTA agreement. To attribute to the economic dimension a causal power for the future events would be a post-hoc fallacy.

Zero-sum logic in the economic dimension was not powerful enough to produce a conflict within Ukraine, but it was one of the factors that provoked the Russian invasion. It was not, however, some specific economic interests that drove Russia to invade Crimea. As mentioned earlier, the Russian president had no clear idea as to how Russian economic interests could be damaged by the EU-Ukraine DCFTA. It was rather the rejection of Russia's desire to 
negotiate the EU-Ukraine relations in a trilateral format that had a strong symbolic effect. The right to negotiate with the EU over various arrangements in Europe has been an important element of Russia's great power identity. The rejection of Russia's claim to take part in negotiations about various, even minor, deals between Europe and the Eastern Neighbourhood challenged Russia's great power status. This led to "geo-politicization" of EU-Ukraine trade issues in Moscow. The Russian side repeatedly described the Eastern Partnership and the DCFTA as a geopolitical plot and an attempt to squeeze Russia out from the post-Soviet space (MFA RF, 2009). The responses to this, such as 'Stop talking about sphere of influence', which EU HRVP C. Ashton produced in her letter to Russian newspapers Kommersant, were read in Moscow as patronizing and insult to Russia's intelligence (Ashton, 2014). However insignificant for the eventual success of the protests, the visits of the EuroMaidan by the US Assistant Secretary of State, V. Nuland, and the representative of the radical wing of the Republic Party, J. McCain, contributed to further politicisation of Maidan in Moscow, which eventually led to Russia's invasion in Ukraine.

The subsequent events demonstrated that there were no specific economic concerns behind Russia's complaints about EU-Ukraine DCFTA. Firstly, when newly elected Ukrainian President Petro Poroshenko signed the EU-Ukraine DCFTA in July 2014, Russia's response was merely rhetorical and not even aggressive. This indifference demonstrates that DCFTA per se does not pose any threat to the economic interests of Russia and Eurasian Customs Union. Secondly, when Ukraine failed to quickly put down the rebellion in the South-East of Ukraine, Kiev suggested organizing a trilateral meeting in the format Ukraine - Eurasian Customs Union - European Union. Russia immediately accepted this offer. At the Trilateral Meeting in Minsk on 23 August 2014, President Putin stressed that the EU refusal to discuss the DCFTA was the reason for deterioration of relations. (Putin, 2014). The absence of any economic rationale behind the crisis was confirmed by the statement of the Kazakh President N. Nazabayev who emphasized that in fact the EU-Ukraine DCFTA would not harm the interests of Kazakhstan, nor consequently Eurasian integration (odnako.su, 2014). All the above suggests that Russia's harsh response to the EU-Ukraine DCFTA arose mostly from the fact that Moscow was not consulted before the negotiations.

It is noticeable that although President Poroshenko signed the EU-Ukraine Association Agreement right after his inauguration, Kiev refrained from disrupting any multilateral negotiations with Russia on potential repercussions for Russia of the EU-Ukraine DCFTA. Although Russia imposed bans on some Ukrainian products, this does not amount to the fully-fledged trade war which Russia waged against Ukraine in July-August 2013. There is continuing consensus between the Ukrainian government, businesses and society for the Free Trade Area with Russia, which is compatible with EU-Ukraine DCFTA. Therefore, despite initial claims about the zero-sum logic, Ukraine appears to be more inclined to accede to DFCTA with the EU without committing itself to deeper and formal integration with Russia. This consensus seems to be currently accepted by Russia. The main obstacle to this process is that a mere trade agreement has acquired a strong symbolic meaning and is linked to great power politics and the dimension foreign policy orientation.

\section{Foreign policy and international security architecture: voluntary Finlandization}

Zero-sum dynamics in the domain of security should be considered within two triangles: NATO-Ukraine-Russia and EU-Ukraine-Russia. The comparison of the two triangles 
demonstrates that the Ukrainian elite and society at large are trying to find a compromise on the international security.

The question of NATO has been controversial because the Orange democratic elite saw Ukraine's speedy membership in NATO as a precondition for Ukraine's European integration, whereas the Party of the Regions (PoR) opposed these plans. Indeed, PoR played an important role in blocking Ukraine's application to NATO Membership Action Plan. But it would be also wrong to explain the negative image of NATO and rejection of Ukraine's accession to the alliance simply by the position of one political party and manipulation by Russian intelligence services, although President Medvedev had implicitly acknowledged the contribution of Russian intelligence to these developments (Medvevdev, 2009).

The main reason for not joining NATO was because Ukrainian society was reluctant to make hasty decisions on such sensitive issues as membership in multilateral defence alliances, whether Russia-led or promoted by the West. This is especially the case when an issue such as this is associated with notions of clandestine diplomacy or corruption. The incident with the secret letter of January 2008, which was signed by President V. Yushchenko, Prime Minister Y. Tymoshenko and Parliamentary speaker A. Yatsenyuk calling on NATO to grant Ukraine the Membership Action Plan (NATO MAP) at the Bucharest summit, made it clear that Ukrainian society was not happy about a hasty accession to the alliance. Apart from the Party of Regions blocking the work of the Parliament on this for about two months, there was also strong public disapproval of the ways in which this NATO MAP was lobbied. Additional scandals with the financing of the NATO-awareness campaign served to further undermine the population's preferences vis a vis NATO (Interview, 2012b). ${ }^{2}$ Popular support for NATO in the period of 2006-2012 dropped from about 16 to $12 \%$ (Razmukov Centre, 2012). The signal from the society was clear - no NATO accession. Thus, even the most committed Euro-Atlanticist Defence Minister Anatoliy Grytsenko (Grytsenko, 2006) has had to accept that Ukrainian society is not ready to make a decision on membership in NATO and he publicly requested the President of Ukraine to withdraw the membership application.(Grytsenko, 2009) Consequently, the Ukrainian elite had to face the fact that Ukrainian society did not want NATO membership. This non-zero sum consensus explains why the extension of basing rights in the Crimea and the adoption of Ukraine's neutrality under the Party of Regions in April 2010 did not provoke serious protests in the Ukrainian society despite fierce resistance of the Ukrainian parliamentary opposition.

Even Russia's annexation of Crimea and the Russian-Ukrainian war in the South-East of Ukraine in 2014 did not reverse this trend. Certainly, these developments caused a significant change in public support for NATO which grew to about $40 \%$. Many opposition parties, such as those led by Y. Tymoshenko and A. Grytsenko, re-introduced the issue of NATO membership to the public debate. However, despite the return of the Euro-Atlanticist idea, the presidential elections have shown that the major centrist trend prevailed in Ukrainian politics. Petr Poroshenko ran for president with explicit pro-European rather than Euro-Atlanticist slogans. After the elections, Poroshenko repeatedly rejected the idea of accession to NATO as it could ruin the country (Interfax, 2014). Even when a significant parliament majority renounced the neutral status of Ukraine, President Poroshenko stated that political speculations about speedy accession to NATO creates new hurdles for Ukraine's Euro-

\footnotetext{
${ }^{2}$ About 12 million USD allocated to several NATO awareness campaigns and embezzled by the Ministry of Foreign Affairs further undermined the idea of Euro-Atlantic integration
} 
Atlantic trajectory. The overall reluctance of NATO to provide tangible support to Ukraine reinforced the perception that NATO should not be considered as the security provider for Ukraine (Poroshenko, 2014).

Speaking about Europe and the European Union one can notice that the link between the European Union and Ukrainian security has been eroded. Certainly, the idea of Europe and European norms and standards remains synonymous with the idea of normal prosperous development. But what is important is that in Ukraine's perception, the European Union in the security domain has been losing its appeal. One of the reasons for the Ukraine's disillusionment in the CFSP, namely is the EU's past failures to stick to its CFSP commitments. For example, in 2004 German diplomats exerted pressure on Ukraine to impose an effective ban on the exports of unregistered Transnistrian enterprises through Ukrainian territory. When Russia exerted pressure on Ukraine to lift the ban, Brussels failed to stand by Moldova and Ukraine. Germany itself did not curtail its extensive collaboration with Transnistrian metallurgy plans. Neither did EU always enforce travel bans on the Transnistrian leadership. Europe's inability to exert pressure on Transnistria and Germany's separate great power deals with Russia caused serious disillusionment among Ukrainian policy-makers:

'Yuschenko was ready to spoil relations with Russia and to host EUBAM. And what
have we eventually got back from this? Merkel and Medvedev discuss Transnistria
behind our back. Well, Medvedev can afford this, he is playing his own game. But
Germany is supposed to display a certain solidarity and appreciation of our effort.
Now, it plays $s$ with Russia because Russia sticks to its values and defends them.
Maybe we should also get arrogant for the EU to start taking us
seriously'(Interview, 2012b)

With Russia's annexation of Crimea and the war in the Eastern Ukraine this disillusionment touched even the most convinced Europeanists. Brussels' refusal to provide Ukraine with military support, the piece-meal adoption of economic sanctions against Russia and the deployment of the EU Assistance Mission with a limited budget and a very weak mandate, have convinced Kyiv to reconsider its security approach. Within the logic of centrist consensus the Ukrainian president followed the Finnish model. This is not to say that Ukraine has renounced its strategic goal to join European security system. It rather means that Kyiv has chosen more self-centred tactics, i.e. it will refrain from strong symbolic steps which could trigger escalation of Russian-Ukrainian war. Within this logic, Ukraine will continue its cooperation with the EU in those fields where it does not inhibit Ukrainian interests, e.g. Ukraine's participation in the EU operations in the Balkans, in the EU naval operation Atalanta, visa liberalisation, justice, security, border control, fight against organised crime, and drug trafficking. Ukraine will also maintain the EUBAM presence on the UkrainianMoldova border (EuropeanCommission, 2011). At the same time, it acknowledges the limitations of the EU's external action. In weighing the EU CFSP against its own national interests, Ukraine will abstain from some strong CFSP resolutions. For example, Kyiv will not exert any pressure against Belarus and will seek temporary alliances with the countries of broader Eurasia.

In the long term, Kyiv will pursue a strategy of increasing its low-profile military defence through practical cooperation with individual players of the Euro-Atlantic Community (e.g. Ukraine's application for the status as a non-NATO strategic ally of the US and development of close military collaboration with Poland, Baltic States). This tactic will allow Ukraine to 
increase its defence capability without creating a risk of large-scale war with Russia. A senior Finnish diplomat stressed that President Poroshenko's strategy resembles the one of Finland's president, Urho Kekkonen, who managed to develop Finland's relations with NATO without antagonizing Russia (Nyberg, 2014).

\section{Dimension of Ideology: national identity, interpretations of history and the language issue}

The conflict in the ideological dimension of the triangle is often "unpacked" as the conflict over the national identity, interpretations of history and the issue of the Russian language. A famous Ukrainian publicist linked these three issuesto the dimension of political practices, arguing that the Yanukovich government sought to weaken Ukraine's national identity as a major obstacle to their authoritarian dominance and replace it with Russian-Soviet-East Slavonic identity, profoundly anti-Western and anti-liberal, that is well established in Russia and Belarus" (Riabchuk, 2012). That has been achieved by the pro-Russian political elite by glorifying the Soviet past, vilifying Ukrainian nationalists and narrowing the space for the Ukrainian language. On the other hand, Russia strengthened this link by arguing that the protests in Kyiv were led by the fascist and Russophobe forces (kremlin.ru, 2014). At first sight the reports of the ultranationalist party "Svoboda" and a new radical group "Right Sector",that were leading the violent protests at Maidan, seem to confirm this kind of interpretation. This section will deal with the fusion of these three concepts - national identity, interpretations of history and the language issue and explores their link to the dimension.

Looking at the Ukrainian revolution and its consequences one can conclude that both above interpretations are reductionist for several reasons. First, active participation of the above ultranationalist parties in the violent protests in February 2014 has not resulted in their growing popularity among the broader society. After the transition of power in FebruaryMarch 2014, these parties effectively lost their dominant position in the opposition movement. During the presidential election the leaders of the two ultranationalist radical parties Oleh Tyahnybok ("Svoboda") and Dmytro Yarosh ("Right Sector") obtained less than two per cent of the votes (IFES, 2014). In the October 2014 parliamentary elections the extreme nationalists failed to pass even the minimum threshold. Similarly, the decline of the "Communist Party of Ukraine", the "Party of the Regions" and "Tymoshenko's block", which relied on pro-Soviet or pro-Ukrainian nationalism, respectively, as well as the ascent of several centrist parties, demonstrate that the expectations of the Ukrainian public opinion turned from an ideologically confrontational to a reconciliatory stance

This new "reconciliatory" paradigm rejects exclusivist policy-choices of ethnic nationalism and envisages dialogue, negotiation and bargain, features more characteristic of civic nationalism. For example, several new political forces, such as the pro-President block "Solidarity-Poroshenko", "Democratic Alliance", "Civil Position" and "Self-Help", feature in their electoral party lists Russian-speakers from Donbas and Ukrainian-speakers activists from Western Ukraine. They also share more or less similar concerns about good governance, corruption and the economy. Most of these parties seek to conduct reforms of government institutions, the army, police and other institutions, in order to reinstall due political process and legitimacy of the state. 
The composition of the Ukrainian government also confirms that the civic nationalist paradigm seems to prevail. A number of top figures in the current Ukrainian government are native Russian-speakers and represent the South and East of the country. President Poroshenko, himself, was born and raised in the Russian-speaking Odessa region (in southern Ukraine). Other examples include, the Russian-speaking Minister of Interior A. Avakov, who started his political career in the East of Ukraine in Kharkov; the speaker of the Parliament O. Turchinov, who comes from the Eastern Ukrainian regional centre Dniepropetrovsk. The similarly multi-ethnic composition of the legislature, judiciary and bureaucracy indicates that the ruling political class is committed to a civic nationalist paradigm.

The war in Donbas provides significant evidence which undermines any potential link between language and alleged pro-Russian, non-democratic preferences. Despite the fact that the part this region has been arena of an intense military conflict, the numbers show that the major proportion of the Russian-speaking community of the region remains loyal to the Ukrainian state project. Although some polls have shown that about 30-percent of the local population support the independence of Donbas, the number of those who would be ready to take arms and fight for an independent Donbas was tiny. The first Defence Minister of the socalled "Donetsk People's Republic", the charismatic Russian officer Igor Girkin-Strelkov, had to admit that the whole Donbas region with a population of 10 million people produced less than a thousand volunteers ready to fight against the "fascist Kyiv junta" for the independence of the Donetsk People's Republic(UNIAN, 2014). At the same time, 14, out of 37 volunteer battalions, fighting against the secessionist forces and the Russian army, were created by the Russian-speaking population of the South-East of Ukraine (Slovo i Delo, 2014). Geographical evidence also shows no clash between Russian-speaking and Ukrainian speaking territories. Despite strong Russian support, the secessionist forces were able to expand their control on just half of the Donetsk oblast and one third of the Luhansk oblast, which is less than $10 \%$ of the territory of the Russian-speaking South-Eastern Ukraine.

While the government and broader public support the civil nationalism paradigm, the big business sectors seem to be divided. For example, some major industrialists in Donbass, such as a major donor to the Party of the Regions, R. Akhmetov, and the Head of the Parliamentary Faction of the Party of Region, Aleksand Efremov, tend to promote the narrative of conflict between the periphery (Donbass) vs. the centre (Kyiv) and support the negotiations for a broad autonomy of the region within Ukraine. It is, however, difficult for this group of businessmen to mobilize significant popular support. There are four main reasons for this. First, they have been heavily compromised both in Kyiv and Russianspeaking regions because of their close links with the Yanukovich government. Secondly, they have repeatedly manipulated the "centre-periphery" discourse in order to mobilize electoral support, but have never managed to deliver on their promises. Eventually, this discourse was hijacked by more radical groups, both local and Russian proxies. As a result, the major businesses lost effective control over the rebels in the region. Thirdly, they are currently opposed by a group of other major industrialists in the region, including I. Kolomoiskiy and S. Taruta, who suffered under Yanukovich and have all the reasons to support the current democratic regime. Fourthly, some of the formerly pro-Yanukovich and neutral oligarchs, such as D. Firtash, a famous intermediary in numerous semi-transparent gas deals decided to support Ukraine's territorial integrity and peace negotiations under the pressure of Western sanctions. Therefore, although divided the business elite of Ukraine appears to o be show a growing sympathy towards a civic national identity. 
Similar to the inclination towards a civic national identity, a reconciliatory approach to the main conflictual points of interpretation of Ukrainian history seems to prevail in the broader Ukrainian society. The pro-Ukrainian narrative victimises Ukrainians and vilifies the Soviet past. The pro-Soviet narrative criminalises Ukrainian nationalism and glorifies the Soviet past. The reconciliatory trend seems to relativize both of them. One of the reasons why the society managed to escape from the conflicting discourse is that both narratives were heavily compromised. The pro-Ukrainian narrative was undermined when nationalist leaders V. Yushchenko and Y. Tymoshenko failed the Orange revolution by implementing ineffective policies and getting involved in corruption and personal quarrels. The pro-Soviet discourse was undermined after the corruption scandals among its main spokesmen, the Communist Party and the Party of Regions. This created favourable conditions for reconciliatory metanarratives. Several examples of such reconciliation between the two parts of Ukrainian society are some highly popular TV-shows, during which high school and university students from the West and the East of the country discussed controversial issues surrounding WWII and the role of Ukrainian nationalism. Broadcast in prime time, these shows were proclaimed by the audience as a model of tolerance for Ukrainian society (Studio, 2011 ENREF 54, Chapai, 2011).

This reconciliatory meta-narrative, which emerged in the broader society, had a knock-on effect on the political elites. This change took place not because of the altruism of the Ukrainian political class. The policy of historical reconciliation has most likely gained ground among various political forces in Ukraine, because it has become clear that any party trying to play one part of the country against the other is unlikely to win significant electoral support. Elections are won by those parties which can attract a critical mass of voters in one of ideologically extreme regions, either the nationalist West or pro-Russian South-East, AND gain some votes in the politically moderate, less ideological Central Ukraine. Therefore, any political forces which try to stir nationalist fanaticism either in Western or Eastern Ukraine are doomed to fail. This Ukrainian political class refused to make a choice between a proSoviet Russian narrative and pro-Ukrainian narrative and, effectively chose a post-modern European metanarrative.

A vivid example of how Ukrainian society departed from the exclusivist conflictual paradigm of the Soviet vs. nationalist interpretations in favour of a reconciliatory approach is the debate which evolved around the celebration of the Soviet Victory Day during 2011-2013. On 9 May 2011 Ukraine witnessed scenes of clashes which took place in the Western part of the country between those who came to commemorate the Victory Day and the local Ukrainian nationalists. After this event, the wider public which participated in polls and public debates did not take sides either with pro-Soviet internationalists, nor with Ukrainian nationalists, but expressed their indignation that the President, Parliament and police allowed violence to happen on that day (Korrespondent.net, 2011). Noticeably, even supporters of Ukrainian nationalism expressed their indignation with the violence rather than with the commemoration of the Soviet Victory Day.

A broader societal condemnation has served as an effective means of "education" even for the ultranationalist party "Svoboda". A year later, the same date was marked more by symbolic and rhetorical stand-offs as -all parties were trying to stress the non-violent character of their actions. This change demonstrates that Ukraine is gradually making a more European choice in the domain of ideology. Indicatively, the spokesman of the nationalist party "Svoboda" in its stronghold West Ukrainian city of Lviv, Markian Lopachak stressed: 
Our community has proved that Lviv is a European city, which shares an international approach to commemoration of the victims of WWII. We can see the outcomes of our outreach and information campaigns... Despite all the efforts of the regime, our community did not yield to provocations and demonstrated complete indifference to the totalitarian Soviet symbols and banners (Pravda, 2013).

Next year, on 9 May 2013, "pro-Russian" President V. Yanukovich almost echoed the words of his predecessor, Ukrainian-nationalist President V. Yushchenko, and called for national peace, dialogue and reconciliation (Zerkalo Nedeli, 2013). The trend prevailed during the presidential and parliamentary elections on 2014. Highly popular President Poroshenko called on all Ukrainians to respects the rights of their compatriots to worship different heroes (TSN, 2014). Trying to address major social concerns, even the most radical leading political parties tend to criticize the Soviet past mostly for the inefficiency of Soviet bureaucracy and economy (Lyashko, 2014) .

Like the government and the broader society, Ukrainian business elites have demonstrated that they have chosen a "reconciliatory" paradigm. On major Ukrainian TV channels, documentaries about the Ukrainian national struggle alternate with Soviet style movies about WWII. Leading industrialists prefer not to take sides with one or another narrative. One could predict that most likely Ukraine will not "criminalize" its Soviet past, like happened in Poland and Baltic states. The fact that the Ukrainian government, elites and society opted for tolerance and reconciliation of the two histories - the Soviet and nationalist - does not make Ukraine an accomplished nation if judged against the standards of Central European nations. This does not mean, however, that the country will remain in Russia's embrace. This trend for tolerance and reconciliation, however, demonstrates that Ukraine has stepped out from the "conflict-generating" trajectory and that Ukrainians are similar to Spaniards, who have reconciled around the heritage of Franco, and Italians who can have their own disagreements about Mussolini, but do not let them to turn into violence.

A similar dynamic can be observed in the discussion about the problem of the Russian language and its status. This issue seems to have lost its social significance because it has been discussed too often and has become overly politicized. In mid March 2012, President Yanukovych stated that he would upgrade the status of the Russian language to the status of the second state language. This pronouncement, which would had stirred a storm a few years ago, hardly produced any effect.(Ivzhenko, 2013) Sociologists argue that the Russian language has lost its potential to mobilize support (Mishchenko, 2012b). It seems that President Yanukovich and his entourage realized this and were not particularly happy when the two significant deputies of the Party of Regions, S. Kivalov and V. Kolesnichenko, brought up this issue for public debate, in the form of a proposed law on regional languages. These attempts obviously did more harm than good to the image of the Party of the Regions and were met with scepticism by the Russian-speaking population, because the card had been repeatedly used by the Party of Regions. Centrists put forward a reasonable argument that proper implementation of all provisions of the law would result in every village and community proclaiming its own regional language, not only Russian, but also Romanian, Hungarian, Bulgarian, etc. That, as centrists argued, would undermine the state institutions and even basic communication between the central and local authorities. As a result of this law, a considerable part of moderate Ukrainian speaking voters, who could potentially vote for PoR, moved to the right, to the Ukrainian nationalists. According to some sources, the two authors of the controversial legislation were not promoted in the electoral party lists, and 
some other significant deputies from the Party of Regions publicly apologized for derogatory statements about the Ukrainian language. (Samokhvalova, 2012). Some of the most active proponents of official reinstating of Russian language were jailed by President Yanukovich repressive machine in 2013-2014.

Further developments with the controversial law about the status of minority languages demonstrate the prevalence of the centrist paradigm. When after the collapse of the Yanukovich regime, the new government and the nationalist forces mobilized support to abolish the controversial law and revoke a special status for the Russian language, acting President $\mathrm{O}$. Turchinov did not hesitate to veto this move. Later on, the new elected President P. Poroshenko confirmed a special status for the Russian language. He gave part of his inaugural speech in Russian and even launched Russian-language news programmes on the national TV channels. Overall, the leading political forces seem to agree not to politicize the question of the Russian language. Most popular parties supporting the current president Poroshenko, his close political ally V. Klychko and his party "Udar", Radical Party of Oleh Lyashko, the Civil Position and Democratic Alliance, prefer not to state any specific political position on the Russian language or give benevolent commitment to promoting national minority languages. Obviously, the removal of the language issue from the political agenda does not imply it has been explicitly resolved and will never reappear in the future. But what is important is that despite their ethnic differences and language preferences, both the Russophones and the Ukrainians seem to seek reconciliatory solutions and mostly reject the idea of violence in bi-communal relations, which is effectively a European paradigm.

\section{CONCLUSIONS}

Placed in the overlapping gravitational field of Russia and the EU, the Ukrainian government, society and business elites are looking for ways to find a balance between their own interests, sometimes even their very survival and Europe's power of attraction and Russia's influence. As the above analysis has shown, the trajectory of Ukraine in each dimension is shaped by the balance of preferences among the main societal actors. As a result, in those dimensions where at least two out of three of these components $s$ find the attractive power of the EU stronger than that of Russia, Ukraine opts for European choice. However, in other dimensions no equilibrium has been found so far.

This paper looked at the Ukraine-Russia-EU triangle from the perspectives of societal practices rather than from the point of view of formal institutions. Drawing on this approach, it can be concluded that Ukraine is gradually moving to the European path of development. Broader Ukrainain society is raising the issues of social equality and fair play and elites are trying to establish a predictable and safe environment. Lame authoritarianism, rigged parliamentary elections in October 2012 combined with ill-implemented neo-liberal reforms, corruption and inefficient governance, stirred public resentment against the Russian version of Ukrainian authoritarianism and led to the democratic revolution in Ukraine in 2014. The fear of some oligarchs for their future, and the defection of numerous members of the proYanukovich Party of the Regions after mass killing of people in Kyiv, resulted in a smooth transition of power from Yanukovich to a new government. The paper has also demonstrated that Russia's uneasy feeling about the democratic revolutions is a function of how Moscow perceives the outcomes of these revolutions. 
In the economic dimension, even under the Yanukovich government, major societal actors agreed that the country should sign EU-Ukraine DCFTA. In 2013-2014 Moscow decided to change the balance of preferences and exerted strong pressure on Ukrainian government and businesses. As a result, the Yanukovich government, backed by the Ukrainian industries, decided to start bargaining and to postpone the signing. This paper has shown that although these developments in the economic dimension (postponement of the signing, rallies in support of the EU-Ukraine DCFTA) were not linked to the dimension of political practices (Ukrainian democratic revolution), Moscow construed these two events as part of a single plot aimed at squeezing Russia out of its traditional sphere of influence and depriving it of the status of great power. Given that Moscow decided to resort to its traditional great power tools, such as the annexation of territories (Crimea) and creation of internal conflicts (Donbass). By annexing Crimea and stirring up conflict in Donbas, Russia effectively undermined its objective economic interests and its authority among the partners in the Eurasian Economic Community and in the international arena. This behaviour reveals a strong link between the economic dimension and the dimension of international security. This suggests that quite often the subjective self-perception of a country may prevail over its costbenefit considerations.

Although Moscow has tied the economic and political dimensions together and decided to act in the military security dimension to prevent Ukraine's further integration with the West, Kyiv keeps trying to decouple the two above dimensions from the military political one. Kyiv seeks to avoid a zero-sum game in the dimension of international security. Its major entrepreneurs refrain from expressing strong Euro-Atlanticist views. Although there is a growing popularity for NATO among the broader Ukrainian public, it is still a relative minority. The majority of Ukrainians and President P. Poroshenko himself continue to stick to a centrist paradigm and refrain from strong symbolic actions, which could provoke further Russia's response. At the same time, the country is eliciting close de facto cooperation with the most active NATO members and is developing low profile defence capabilities.

In the dimension of ideology, Ukrainians seem to be moving away from the conflictual paradigm and an inclusive civic national identity is being developed. The question of Russian language is losing its political significance. Having lived with strong polarisations around ideological issues, Ukrainians appear to be developing immunity against political and ideological extremes. The decline of far right political parties (both pro-Ukrainian and proRussian) indicates the emerging centrist consensus. Even if a national consensus about the interpretations of history is unlikely to be achieved in the midterm, the Ukrainian ruling elite and wider society seem to be learning from their own mistakes and want to avoid societal violent stand-offs around history. Despite a measure of support in Donetsk and Crimea to secession from Ukraine, the Russian-speaking community has largely ignored the calls of Russian leaders to join the fight for independence of the self-proclaimed republics of Donetsk and Luhansk. The geographical area controlled by these entities remains very small. Thus, one can conclude that Ukraine is moving on to European path of development by a) reaching broader consensus on less controversial issues; b) by relativizing some of the more controversial issues, and c) by refraining from certain actions that could generate zero-sum logic in the EU-Russia context.

This paper has shown that a multidimensional analysis can provide deeper insight into complex dynamics and controversial phenomena of the Ukrainian crisis. Slicing the EU- 
Ukraine-Russia triangle allows to identify and deconstruct links between various dimensions and create areas for meaningful peace dialogue.

\section{REFERENCES}

2013. Opozytsiynyi shtab natsionalnogo sprotyvu ogoloshue zagalnonatsionalny straik. Tyzhden', 30 November 2013.

ASLUND, A. 2008. An Assessment of Putin's Economic Policy. CESifo Forum, 9, 16-21.

ASHTON, C, 2014. Khvatit rassuzhdati o sferakh vliania, Kommersant, 18 Feb. 2014

AZAROV, M. 2012. Ukraina gotova doluchytsia do budivnytstvo Transanatoloiyskogo gazoporovodu. Kyiv: Department of Information and Communication of the Secretariat of the Cabinet of Ministers of Ukraine.

CHAPAl, A. 2011. Podorozh z Mamayotoyu: V Poshukah Ukrainy, Kyiv, Nora Druk.

CIUTĂ, F. 2008. Region? Why Region? Security, Hermeneutics, and the Making of the Black Sea Region. Geopolitics, 13, 120-147.

CIUTĂ, F. 2007. Parting the Black Sea (Region): Geopolitics, Institutionalisation and the Reconfiguration of European Security. European Security, 16, 51-78.

COOPER, R. 2011. The Breaking of Nations: The Order and Chaos in the Twenty-First Century, London, Atlantis Books.

D'ANIERI, P. (ed.) 2011. Orange Revolution and Aftermath: Mobilization, Apathy, and the State in Ukraine.

, Baltimore, MD:: Johns Hopkins University Press.

DELCOUR, L. 2010. The European Union, a security provider in the eastern neighbourhood? . European Security, 19, 535-549.

DYMOV, V. 2012. Partiya Regionov tochit zub na Poroshenko. Available: http://www.unian.net/news/501299-partiya-regionov-tochit-zub-na-poroshenko.html.

EMERSON, M. 2001. The Elephant and the Bear: The European Union, Russia and their Near Abroads, Brussels, CEPS.

EUROPEANCOMMISSION 2011. Implementation of the European Neighbourhood Policy in 2010. Country Report: Ukraine. Brussels.

GATSKOVA, K. 2013. Distributive justice attitudes in Ukraine: Need, desert or social minimum? Communist and Post-Communist Studies, XXX, 1-15.

GAVRILECHKO, Y. 2010. Zona Svobodnoy Torgovli: Prevratnosnit Ukrainskogo Puti. Available: http://www.experts.in.ua/inform/smi/detail.php?ID=71164.

GERMAN, T. C. 2007. Visibly Invisible: EU Engagement in the Conflict Resolution in the South Caucasus. European Security, 16, 357-374.

GOMART, T. 2006. The EU and Russia: The Needed Balance between Geopolitics and Regionalism. Russie.Nei.Visions. IFRI.

GRYTSENKO, A. 2006. Anatoliy Grytsenko upevneniy shcho do momentu uhvalenniya rishenniya pro pryiom Ukrainy v NATO ukrains'ke suspilstvo bude gotovo pidtrymaty. Kyiv: Press Sergive of the Ministry of Defence of Ukraine.

GRYTSENKO, A. 2009. Voina mezhdu Ukrainoi i Rossiey stala by katastrofoi. Gazeta.Ua [Online]. Available: http://gazeta.ua/post/300413 [Accessed 2 March 2013].

HAUKKALA, H. 2008. Multi-causal social mechanisms and the study of international institutionalisation : the case of EU-Russia strategic partnership. The University of Turku.

HILL, W. H. 2012. Russia, the Near Abroad, and the West: Lessons from the Moldova-Transdniestria Conflict, Washington, Wilson Centre.

HISKI HAUKKALA, S. M. E. 2001. The EU Common Strategy on Russia; Learning Grammar of the CFSP, Helsinki/Berlin, The Finnish Institute of International Affairs. 
HOWARTH, R. 2011. Putin's 'Preventive Counter-Revolution': Post-Soviet Authoritarianism and the Spectre of Velvet Revolution. Europe-Asia Studies, Vol. 63, 1-25.

INTERVIEW. June 2011 2011. RE: Diplomat, the Russian MFA

INTERVIEW. March 2012 2012a. RE: Party of Regions.

INTERVIEW. June 2012 2012b. RE: Ukrainian diplomat, MFA.

IVZHENKO, T. 2013. Kiev beret na sebia nevypolnimye obiazatelstva. Nezavisimaya Gazeta, 20 March 2012.

IZVESTIA. 2004. Gleb Pavlovskiy: Yuschenko Nevzliubili v Rossi eshe ranshe chem poliubili Yanukovicha. Izvestia, 1 Nov. 2004.

KORRESPONDENT.NET. 2011. Opros: Bolshynstvo Lvovian schiatyut shto v sobytiah 9 Maia vinovny pro-rossiyskie sily. Korrespondent [Online]. Available: http://korrespondent.net/ukraine/politics/1224522-opros-bolshinstvo-Ivovyan-schitayutchto-vinovnymi-v-sobytiyah-9-maya-yavlyayutsya-prorossijskie-sily.

LANE, D. 2009. Coloured Revolution' as a Political Phenomenon. Journal of Communist Studies and Transition Politics, 25, 132.

LANGENHOVE, L. V. 2003. Theorising Regionhood. UNU/CRIS e-Working Papers [Online].

LANGENHOVE, L. V. 2011. Building Regions: The Regionalization of the World Order, interaction in conflict resolution Ashgate.

LESHCHENKO, S. 2013. Ukraine: Yanukovych's 'Family' spreads its tentacles. Open Democracy [Online]. Available: http://www.opendemocracy.net/od-russia/sergii-leshchenko/ukraineyanukovychs-family-spreads-its-tentacles [Accessed 29 January 2013].

LEVYBEREG. 2012. Istochnik: Azarov podpisal vygodniy dlia Rossii dogovor o ZST v SNG bez soglasiya Yanukovicha. Leby Bereg.

LUTSEVYCH, O. 2013. How to Finish a Revolution: Civil Society and Democracy in Georgia, Moldova and Ukraine. Briefing Paper. London: Chatham House.

MARAT, E. 2010. Russian Mass Media Attack Bakiyev. Eurasia Daily Monitor.

MEDVEVDEV, D. 2009. Vystuplenie na Rasshyrennom Zasedanii Kollegii Federalnoi Sluzhby Bezopasnosti.

MILOV, V. 2011. Sushchestvuyet li rossiysko-ukrainskaya druzhba? In: BUNTMAN, S. (ed.) Klinch. Moscow: Radio Eho Moskvy.

MISHCHENKO, M. 2012a. Balancing on the election threshold in Ukraine: "Civic Position" gains, "Svoboda" loses'. Brief. Kyiv: Razumkov Center.

MISHCHENKO, M. 2012b. Spaset li Yanukovicha povyshenie statusa russkogo yazyka'. Available: http://www.unian.net/news/493259-spaset-li-yanukovicha-povyishenie-statusa-russkogoyazyika.html.

NAJŠLOVÁ, L. 2010. The EU in the Wider Black Sea Region: Clumsy but Attractive? . In: K. HENDERSON, C. W. (ed.) The Black Sea Region and EU Policy : The Challenge of Divergent Agendas. Ashgate: Surrey\&Burlington.

NITOIU, C. 2011. Reconceptualizing 'Cooperation' in EU-Russia Relations, Perspectives on European Politics and Society. 12, 4, 462-476.

OBOZREVATEL'. 2011. Putin sulit 'zolotyie gory' Ukraine zavstuplenie v TS. Obozrevatel' [Online]. Available: http://obozrevatel.com/politics/putin-sulit-ukraine-zolotyie-goryi-za-vstuplenie-vts.htm.

POROSHENKO, P. 2014, Rechi Poroshenko pered Novoi Radoi: Polny Tekst, Zerkalo Nedeli, 27 Nov. $\underline{2014}$

POTEMKINA, O. 2010. EU-Russia cooperation on the common space of freedom, security and justice - a challenge or an opportunity? European Security, 19.

PRAVDA, U. 2013. "Svoboda" radie scho ne dopustyla shabashu u Lvovi. Ale prapor zabrala. Ukrainska Pravda [Online]. Available: http://www.pravda.com.ua/news/2013/05/9/6989564/ [Accessed 12 May 2013]. 
PROZOROV, S. 2006. Understanding Conflict Between Russia and the EU, London, Palgrave.

RIA. 2011. Putin rasskazal, chtodast Ukraine vstupleniye v Tamozhenniy Soyuz. RIA Novosti [Online]. Available: http://ria.ru/tvpolitics/20110412/363791591.html [Accessed 20 January 2013

].

RIABCHUK, M. 2012. Ukraine's 'muddling through': National identity and postcommunist transition. Communist and Post-Communist Studies, 45, 1-8.

ROSBALT. 2013. Glaziev: Ukraina s assotsiatsiei s ES navsegda zakryvaet dveri v Tamozhenyi Soyuz. Rosbalt [Online]. [Accessed 09.05.2013].

SAMOKHVALOVA, L. 2012. Nikolay Levchenko: la prinoshu svoi izvinenia za to, shot govoril ranshe. Available: $\quad$ http://www.unian.net/news/541789-nikolay-levchenko-ya-prinoshu-svoiizvineniya-za-to-chto-govoril-ranshe.html.

SHEVCHENKO, A. 2013. Zolotaryov 'Sprava Tymoshenko pogany znak dlia Pinchuka ta Komois'kogo. Kyiv: TVI channel.

SHUMYLO-TAPIOLA, O. 2012a. The Eurasian Customs Union: Friend or Foe of the EU? The Carnegie Papers. Brussels: Carnegie Endowment.

SHUMYLO-TAPIOLA, O. 2012b. Ukraine at the Crossroads: Between the EU DCFTA and Customs Unio. Russie. Nei.Reports. Paris: French Institute of International Relations.

STOROZHEV, R. 2012. Slantsevaya alternativa: Komu dostanutsia ukrainskie mestorozhdenia. Available: $\quad$ http://liga.net/opinion/33780 slantsevaya-alternativa-komu-dostanutsyaukrainskie-mestorozhdeniya.htm.

STUDIO, S. S. 2011. Svoboda Slova. In: SHUSTER, S. (ed.) TV Talk Show Shuster Live, .

TOPALOV, A. 2011. Vekselberg prodaet trubu. Gazeta.Ru [Online]. Available: http://www.gazeta.ru/business/2011/07/11/3691965.shtml.

TSYMBALIUK, R. 2012. V Moskve Yanukovichu gotoviat sudbu Lukashenko. UNIAN [Online]. Available: http://www.unian.net/news/501767-v-moskve-yanukovichu-gotovyat-sudbulukashenko.html [Accessed 5 May 2012].

Press Conference, 2011. Directed by VLADIMIR PUTIN. Moscow: Press Deparment of Prime Minister of the Russian Federation.

WILSON, A. 2005. Virtual Politics: Faking Democracy in the Post-Soviet World, New Haven, CT \& London, Yale University Press.

YANUKOVICH, V. 2013. Ukaz Pro Upovnovazhennogo Ukrainy z pytan' zovnishyopolitychnykh ta integratsiynykh protsesiv [Online]. Kyiv. Available: http://www.president.gov.ua/documents/15719.html. 